\section{Public/private partnerships, at what price?}

From a scientific viewpoint, Huizenga and colleagues are completely right to endorse 'disruption' by public-private partnerships as a way to 'accelerate innovation and enable translation of the rapidly expanding cellular and molecular understanding of disease pathogenesis into the development of new therapeutic agents'. ${ }^{1}$ However, one of their examples (monoclonal antibodies leading to the development of anti-tumour necrosis factor (TNF) treatment) highlights an aspect they did not discuss: publicly funded science leading to drugs marketed at prices society cannot afford.

In my opinion, the current model of drug development is broke and also needs to be disrupted. I say this in full awareness of the many great advances for example the field of rheumatology has enjoyed. A recent study by SOMO, an independent organisation that researches multinationals, suggests that pharmaceutical companies have switched from innovation to financial instruments in order to sustain themselves and increase their profitability. ${ }^{2}$ Also, drug development is mostly targeted at areas of high potential profit, including diseases where orphan status can be obtained, rather than areas of high societal need. From the company's and shareholder's viewpoint, this is entirely legitimate.

But from the societal viewpoint, it is highly suboptimal. We need to fundamentally rethink how we want to progress science and drug development, so that new treatments can become available at affordable prices. As an aside, this includes a rethink on the outrageously complex, slow and expensive process of drug approval.

For now, scientists and society should become less naive and wary of partnerships in which they offer knowledge 'for free', with nothing in return except the opportunity to buy back the results of their knowledge at premium prices.
Maarten Boers $\oplus^{1,2}$

${ }^{1}$ Epidemiology \& Biostatistics, Amsterdam UMC—VUMC location, Amsterdam, The Netherlands

${ }^{2}$ Amsterdam Rheumatology and Immunology Center, Amsterdam UMC - VUMC location, Amsterdam, The Netherlands

Correspondence to Professor Maarten Boers, Epidemiology \& Biostatistics, Amsterdam UMC—VUMC location, Amsterdam 1081, The Netherlands; eb@vumc. $\mathrm{nl}$

Funding The authors have not declared a specific grant for this research from any funding agency in the public, commercial or not-for-profit sectors.

Competing interests None declared.

Patient and public involvement Patients and/or the public were not involved in the design, or conduct, or reporting, or dissemination plans of this research.

Patient consent for publication Not required.

Provenance and peer review Not commissioned; internally peer reviewed.

(c) Author(s) (or their employer(s)) 2020. No commercial re-use. See rights and permissions. Published by BMJ.

\section{Check for updates}

To cite Boers M. Ann Rheum Dis Epub ahead of print: [please include Day Month Year]. doi:10.1136/annrheumdis-2020-217664

Received 18 April 2020

Accepted 21 April 2020

Ann Rheum Dis 2020;0:1. doi:10.1136/annrheumdis-2020-217664

ORCID iD

Maarten Boers http://orcid.org/0000-0002-6969-283X

\section{REFERENCES}

1 Huizinga TW, Holers VM, Anolik J, et al. Disruptive innovation in rheumatology: new networks of global public-private partnerships are needed to take advantage of scientific progress. Ann Rheum Dis 2020;79:553-5.

2 Available: https://www.somo.n//private-gains-we-can-ill-afford/ [Accessed $18 \mathrm{Apr}$ 2020]. 